\title{
Economic Development-Based on Local Tourism in Yogyakarta
}

\section{LISTIANA ASWORO}

\author{
Government Studies of Muhammadiyah Malang \\ University (UMM) \\ listianaasworoO6@gmail.com
}

\begin{abstract}
Tourism sector has long been referred to as economic sector. It is believed that tourism is one of the factors causing multiplier effectthat result in welfare on one side and community empowerment on another side. In order to realize the multiplier, effect all stakeholders should work in a synergy to develop tourism-based local economics. The article described how bottom-up approach, empowerment and local wisdom had given positive contribution towards tourism sector in Gua Pindul and at the same time improved the local economics.
\end{abstract}

Keywords: tourism; local economic development; empowerment

\begin{abstract}
ABSTRAK
Sektor pariwisata telah lama disebut sebagai sektor ekonomi. Pariwisata menjadi salah satu faktor yang diyakini mampu memberikan multiplier effect dengan memberikan efek kesejahteraan di satu sisi dan pember- dayaan masyarakat di sisi yang lain. Namun, upaya ini harus didukung olehsemuastakeholderyangsalingbersinergidalammembangunekonomi lokal berbasis pariwisata. Tulisan ini hendak menyampaikan bahwa obyek wisata Gua Pindul yang dikembangkan melalui gagasan bottom up dan dengan logika pemberdayaan serta didukung dengan kearifan lokal telah mem- berikan dampak positif, yakni dapat mensejahterakan masyarakat sekitar.
\end{abstract}

Kata Kunci: pariwisata; pembangunan ekonomi lokal;pemberdayaan

\section{INTRODUCTION}

The article aimed to describe how the caves located in Bejiharjo village, Gunung Kidul, Yogyakarta was developed using local-based tourism development and how the method develop local economics in Bejiharjo village. Starting from the local initiative, Bejiharjo has turned into tourist village in which nature and its harmony become its selling points. Local wisdom is a factor that attracts visitors. It is important to pay attention to the environment, more particularly local 
environment, while improving tourism sector in one place. Stakeholders in Beji harjo village have succeeded in finding a balance between ecological and economic aspects.

Indonesia has exotic landscape stretching from Sabang to Merauke. Natural wonders and cultural heritage from Indonesia have received international recognition. Therefore, tourism sector has become the major contributor for the national foreign exchange besides the mining sector.

Discussions on tourism sector have always raised the following questions such as which concept is the most suitable one to manage the national tourism sector, which institution, private or public institution, is responsible for managing the national tourism sector (land ownership and other facilities such as hotel, restaurant, and tour operators)and when localbased tourist development, which emphasizes on local participation to manage local tourist industry, should be started (Setyawan 2008).

Such discussion starts with "domination" on tourism concept which massively becomes reference or platform in tourist management. International tourism sector has created standardized and organized criteria or packages focusing on flexibility, segmentation and diagonal integration. It means the concept or idea of conventional management did not involve cultural aspects as another basis to manage tourism sector. The idea international tourism network offered is not more than sales but neglecting other crucial value such as local welfare (Sugiantoro 2000).

Historical documents have showed that at the beginning of $1970 \mathrm{~s}$ the international tourism sector practiced in the developing countries was not panacea or effective formula in developing the economics or the local financial status. It has failed to run its function as generator of economic development in the developing countries. Worse, the concept has resulted 
in some drawbacks and dependence. In addition, some studies focusing on tourism in developing countries have revealed some deficit as the immediate impact of investors and companies from the developed countries taking over local tourism sector. The World Bank noted that 55\% of the developing countries foreign exchange in tourism sector is going to the developed countries that managed their tourism sectors (Sugiantoro 2000).

Based on such complexity the new division of international tourism or local-based tourism management is born in developing countries. It serves as alternative idea in managing tourism sector so that growth of economics and local welfare can be achieved. Even though it is a pretty recent concept, it has changed tourism configuration in developing countries fundamentally. The most significant difference between the concept and the previous one is that the recent concept understands the vital role of local community in local tourism management.

Local-based tourism trend also put more emphasis on local wisdom that highlights local living quality. It means the approach offers different tourist management concept; not only does it prepare facilities and infrastructure, but it also prepares professional, friendly staffs as well as so there technical matters. Yet, substantially, an aspect to emphasize is tourist package that shows tradition, custom or culture of an area. Tourist package should offer not only natural beauty but also habit of the locals which obviously different from that in visitors place (Sugiantoro 2000).

\section{LITERATURE REVIEW}

\section{Local Tourism Concept}

Studies on the development of community-based tourism (community-based tourism) has a lot to do. For example, studies conducted by (Satria 2005), (Othman and Rosli 2011), Lopez-Gusman (2011), (Widowati 2012) and 
Nurhayati (2013). The research they have done more emphasis on aspects of community participation as one of the main factors in the development of tourism (Suasapha 2016). However, it has not been entered on the landscape that the development of community-based tourism has positively correlated to increased economy and the well-being of local people. Analytic construction of the knife through the local economy (Local Economic Development), tourism run by the society actively participate in developing the tourism in the regions turned out to give a trickledown effect in its application. Not just a matter of the welfare and the economy improved, but about local wisdom are also deters preserved.

The development of the tourism industry that emphasizes aspects of local wisdom by initiation and participation from the community has been shifting dominance orientation of mass tourism. If the formerly rated as the success of the development of tourism is a large number of tourists. Today, that view is shift dealing with the emergence of alternative tourism which put more emphasis on appreciation and appreciation for aspects of sustainability, such as the quantity of a non-natural, environmental and cultural. Therefore, the come upconcept of community-based tourism development or community-based tourism (CBT) model that is, tourism involving local communities by providing the opportunity to manage and build tourism, good directly or indirectly which has linkages with the industry or tourism businesses, so that the distribution of the profits evenly on the Community (son: 2015in Barcelona:2016:176).

Management of community-based tourism industry (bottom-up) has its own advantages than the management of the tourism sector which was initiated by the Government (top-down). There is a fundamental difference between the two. If the management of tourism through a bottom up initiative isa form of society, then the development of tourism with 
the approach of top-down emphasis on more sustainable tourism which was initiated by the Government (Suasapha 2016). This means that the difference in how to manage the tourism industry will also affect the shape of the tourism offer. The Government-run tourism generally shaped visualization, large profit-oriented and often collaborate with private parties. While the tourism was initiated from the creativity of the community features characteristic of its territory, with the concept of back to nature, as well as to introduce the local culture. Thus, community- based tourism is not a rigid concept and monotonous. The concept of community-based tourism has the uniqueness and specificity of each, because each region has a variety of different culture and nature between each other (Suasapha 2016). Potentialities of tourism in areas that should be caught by the local community to develop its tourism and get economic surplus of tourism management. Thus, the positive impact of community-based tourism management local economic development can be realized.

Community or local-based contemporary tourism industry management has started to be applied in Indonesia. One of tourism management applying the concept is the one in Gua Pindul of which location is in Beji harjo villa. Bottom-up concept is a tourist management concept in which local society is the one taking control of tourist management in Gua Pindul. At the same time, the government acts as facilitator and advising how Gua Pindul should be developed in the future. This way financially-independent and empowered society can be achieved.

Bottom-up approach offers job vacancy for the locals since the locals are the one actively manage tourism sector in their area. As the result, the locals become financially independent. Besides Gua Pindul, the locals also develop local wisdom or heritage-based tourism. Tourist package they offer consists of 
caving in Gua Pindul and local wisdom in Bejiharjo village. Habit of the local is another factor that attracts visitors. Introducing their habit to visitors enables the locals to show their custom to the visitors and at the same time, preserve their local culture. Applying the bottom-up concept and social empowerment, Gua Pindul tourist management becomes example for other tourist management in both national and international level.

Prior to further discussions, there are some related concepts to explain. Tourism concept or idea is not a single concept. There are many definitions with different emphasis. Using the international tourism concept as reference, tourism according to WTO (as cited in Richardson \& Flicker) is: "The activities of persons traveling to and staying in places outside their usual environment for not more than one consecutive year for leisure, business and other purposes" (Pitana 2009

Another alternative is local or community-based tourist development that statestion the locals, by the locals and for the locals". The local-based tourism is a concept designed for providing economic, social and cultural benefit for the local society.

On the other hand, according to R.S Damarjati, tourism industry is summary of various sectors of business that simultaneously provides product and service which later directly or indirectly are needed by visitors during their stay. Tourism as an industry was first recognized in Indonesia after the 1969 Presidential Instruction number 9 was issued on August, 6, 1969. In Chapter II Article 3 of the Presidential Instruction, it is stated that: "Efforts to develop tourism in Indonesia is a development of "tourism industry "and part

Of effort to improve and develop social and national welfare." (Oka). 


\section{RESEARCH METHOD}

This Research includes the types of qualitative research by using the case study method. Consideration of the use of more qualitative type of research study that is due to be the focus of this research dielaborasi and more can be explored when using qualitative research design. Qualitative design helps this research became more in-depth and purposeful. The method of case study also assessed suitable for the control of this research requires inter connection in the process of his research (Denzin and Lincoln 1994). Therefore, the appropriate case study method is used to get the answers research who wish to take the opportunities and challenges in the development of the local economy in the village of Bejiharjo.

The use of case studies in research is more due to the focus of the studies that will be scrutinized is a single case like to thoroughly peeled or comprehensive (Babbie 2015). In addition, the use of the case study method is appropriate because it can be a tool to get and explore the data required. The method of case study also fits into a series of analytical instruments in this research. First, the formulation of the problem using the word ask how, that implicitly reflected in the focus of the research is to understand how the opportunities and challenges for building the local economy-based tourism. Second, this research is contemporary research or are based on the present focus and locus of research. Third, in this study the researchers do not have the opportunity to control the phenomenon being studied (Yin 2009).

As research methods, (Shaughnessy and Zechmeister 1990) this case study is not merely an instrument or data collection techniques. Methodological concerns but also has the ability to pave the way for discoveries, insights, even hypotheses which are capable of developing advanced studies (L BERG 2001). So, these methods also contribute 
Vol. 1 No.1

March2018

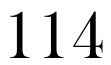

to the development of science. Case studies are also able to give scientific valve with the objectiveness of articulation that seeks researchers, anality strategy, and also not just focused on the phenomenon or event that is examined. But instead provide insight into events or phenomena of what was happening ( $\mathrm{L}$ BERG 2001).

The source of the data in this study are derived from primary data and secondary data. Primary data include the words and actions of informants (Moleong 2008). Secondary data include, observation, document (data source is written), and photos. In this study, more dominant primary data used to find answers to the question of research. However, at some point, secondary data was presented not only as a complement or snacks that assert the primary data, but could be a reference to find the answers to the research. South at data retrieval this in research using the technique of multi slumber evidence (Yin 2009). The position of the primary data in research is important. The urgency of the primary data being a measure of the validity of the research. That is, this research can be accounted for. Nevertheless, the position of the secondary data is also very necessary in an attempt to gather the data as much as possible. With the affirmation of secondary data through implied through observation, official documents, as well as the photos that successfully compiled, then the research is much more valid.

Thus, primary data and secondary data are equally needed in this research that position overlapped with one another as a series of data. Primary data present as an attempt of clarification and explanation of the research question posed through process of questioning. Meanwhile, secondary data also cannot be ignored because it can become an instrument of snacks that assert. With the gathering together, the primary data and secondary data that maximum, then the research will obtain the enriched data. 
How to collect the data is carried out by means of direct observation to the location of research and in-depth interview in an instrument to get comprehensive answers. An in-depth interview process conducted in ways which are familial and are not intimidate. So, with a fluid and relaxed the informant will freely tell you. In addition, the authors also use the interview guide as the controller of the course of the interview process. However, the interview guide not only serves as a controller, but also to do a check list to questions in order to develop questions. For a technical analysis of data, the first step in the research is done with pereduksian data. Pereduksian data serves to classify the core data and data that is not associated with the research. The second step is by empirical research. The core data that have been collected are then assembled into a relationship of causality to answer and explain the focus of the research(Yin 2009). Lastly, the conclusion made in interpretative analysis-based field findings and data analysis (Esterberg 2002) that proves that local economic development is driven through a community- based tourism has given the impact positive towards the welfare of the community.

\section{RESULT AND DISCUSSION}

\section{Stakeholder Role: Creating Local Economic Development in Be- jiharjo Village}

Once again, community-based tourism puts emphasis on balance and synergy between actors, government and private institutions. Although the community-based tourism considers local society as the main component tor actors, other actors are also necessary. The model demands coordination and cooperation between actors. Therefore, it is important to identify roles of each of the actors (Demartoto 2009).

In managing Gua Pindul, the society has privilege as they are central in developing tourism sector in Bejiharjo, 
Vol. 1 No.1

March2018

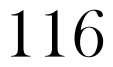

Including Gua Pindul. However, other actors also have contribution in improving the local welfare indicated by raising income. The local community is supported by other actors who have various different roles and functions. Coordination and cooperation are the requirement to achieve community welfare. There are three actors having major contribution in developing local economics. The following section describes and analyzes role and contribution of the sectors.

\section{Government}

Government, in this context, refers to both central and regional government with either immediate or non-immediate role (Pitana 2009

). The government has issued the 1996 Decree number 67 about tourist administration. Regulation on foundation and objective of tourism, tourist attraction and object, tourism business, public participation, development, delegation and others indicate that the government has political willing to develop tourism sector in Indonesia. The 1999 Decree number 22 about regional government explains that regional government is authorized and responsible for tourist administration in an area (Gelgel 2006).

Because of decentralization and local autonomy, the regional government of Gunung Kidul Regency has pivotal role in developing tourism industry in their area. Related to the development of Gua Pindul, a tourist attraction in Bejiharjo, Yunus a staff in Tourism Development of the Department of Culture and Tourism of Gunung Kidul stated that the first role of the government was to prepare the local people in Bejiharjo to shift from being farmers to working in tourism sectors through reflective methods (giving explanation about tourism sector). The second was that the regional government conducted some training on the methods to develop Gua Pindul as tourist at traction, for instant detraining one emergency procedure, tour-guiding, culinary and homestay; the 
government occasionally invited some academics to these workshops. The third was that the government became facilitator or mediator for conflict resolution between the locals and land owner.

The biggest challenge in developing Gua Pindul as tourist attraction was lacking coordination as some actors had different ideas and perspectives (Yunus 2014). He further explained that lacking coordination was due to the locals having full authority to manage the tourist attraction. Another challenge was to preserve the ecosystem and minimize damage to the environment. The tourist management of Gua Pindul would become model for other tourist attraction manager in other areas in Indonesia or foreign countries (Yunus 2014). Others would start using community-based tourism too. Gua Pindul has now become reference or object of studies for institutions of which interest or responsibility is tourism. As the result, Gua Pindul is getting more and more famous. He further states that Bejiharjo will improve from heritage village, launched in2008, intolargertourist village.

\section{Local Community}

In community-based tourism, local community is the key of successful management of particular tourist destination. In every step, starting from planning, administration, management, development to supervision and evaluation, the locals in Bejiharjo has such a tremendous role since empowerment is the major principle. Bottom-up approach is the true concept of developing Gua Pindul as tourist attraction since three locals Subagyo, Tukijo and Ratmin were the pioneers in Gua Pindul caving idea. With their own initiatives, the locals started to design and execute their ideas. They also work with other related institutions and organizations such as"Basarnas" that conduct training for safety of visitors and foreign language institutions for tour-guiding training. 
Vol. 1 No.1 March2018

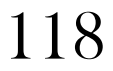

Besides that, it is equally important to maintain image as tourist attraction that sells local wisdom to attract visitors. The locals in Bejiharjo treat their local wisdom and indigenous characteristics as their assets. The locals also divide roles in the tourist management in the area. For example, the community groups in the area take turn to provide food and snacks to sell. According to Subagyo ,one-of-a-kind home stay concept the locals provide, in which visitors sleep on rattan mat without any mattress, becomes another factor that attracts visitors to come to the village.

Subagyo mentioned the challenge in developing tourismbased local economics in Gua Pindul is conflicts between the tourist management and the land owner. Although the conflict caused some inconvenience, the number of visitors is stable. The number of visitors is increasing because they are curious about the conflict. Gua Pindul offers business opportunity and job vacancy because the area does not have local souvenir yet.

\section{Private Institutions}

Private institution is one of the actors that is involved in community-based tourism. In Gua Pindul, the only private institution involved was Bank BPD who built some gazebos for resting. Both the government of Gunung Kidul and the locals in Bejiharjo believe that private institutions will become dominant actor if they are involved in tourist management of Gua Pindul. Therefore, private institution is not allowed to make investment because it does not match the principles of community-based tourism or may minimize local income. Subagyo revealed that numerous local and international private institutions are interested in making investment in Bejiharjo.

\section{Gua Pindul: Empowering Local Economics}

Gua Pindul is located in Bejiharjo, a village developed into tourist village in which its nature becomes the selling 
point. Nowadays, a lot of domestic and foreign visitors come to tourist attraction in the village. One of the tourist attractions in the village is Gua Pindul that lies in an area called Gelaran. Visitors coming to Gua Pindul can experience cave tubing, which many find pretty adventurous.

The locals are familiar with Gua Pindul. Before being developed into a tourist attraction, the cave is the location for swallow nest and the locals used its water for irrigation. A group of people, Subagyo, Tukijo, and Ratmin realized that the cave has tremendous potential to explore. These three pioneers started to make some plans with Karang Taruna Desa Bejiharjo, an organization for young locals. They on cowered uncertain their plans would succeed since the locals in Bejiharjo still consider the cave as sacred place.

The locals eventually responded positively towards the plan and supported it. The first step they did to transform Gua Pindul into a tourist attraction was to establish Kelompok Pengelola Desa Wisata Bejiharjo (Dewa Bejo) on June2010. This organization is responsible for tourism management in Gua Pindul. The government of Bejiharjo village gave their blessing. This organization started working by renting a house from one of the locals as headquarter. They also borrowed some tubes and safety jackets from the organizations in Kali Suci in Semanu. On October, 102010 Gua Pindul tourist attraction was established for the first time by the Head of Gunung Kidul Regency at that time, the late Prof. Ir. Sumperno Puro. The admission fee was 30,000 to 45,000 rupiahs.In2011, Pokdarwis (Kelompok Sadar Wisata)Dewa Bejo received 50 million rupiahs funding from PNPM Mandiri Pariwisata. These funding was used for building some facility such as toilets and buying more tubes and safety jackets. Intensive promotion using various mass media is the key to attract visitors to Gua Pindul. 
Table 1. Increasing Number of Visitors and Income

\begin{tabular}{|l|l|l|l|l|}
\hline & \multicolumn{1}{|c|}{2010} & \multicolumn{1}{c|}{2011} & \multicolumn{1}{c|}{2012} & \multicolumn{1}{c|}{2013} \\
\hline Visitor (person) & 98 & 4,928 & 59,312 & 312,746 \\
\hline Income (rupiah) & 460,000 & 162 million & 1.8 billion & 10 billion \\
\hline
\end{tabular}

Seeing sharp increase in the local income, The Ministry of Tourism and Creative Economics awarded Gua Pindul as the best tourist village in 2012. At this time, Bejiharjo competed against other tourist villages in like the ones in Bali. Gua Pindul is also one of the top 15 national tourist attraction. The local income far exceeds the total regional income of Gunung Kidul Regency at 5 billion rupiahs. Subagyo reiterates that the locals did not share any of these income to the regional government of Gunung Kidul Regency because Gua Pindul was developed based on community-based tourism.

Gua Pindul has received various awards because it has been successful in the implementation of community-based tourism and increasing local income. The locals started to become financially independent because they take active participation in managing Gua Pindul as tourist attraction. The objective of community-based tourism is to give economics, social and cultural a benefit for the society so that locals can increase their quality of lives. The model allows local community to fight against poverty. It is similar to pro-poor tourism approach that gives access to low economic society to participate in tourism sector (Demartoto 2009). 


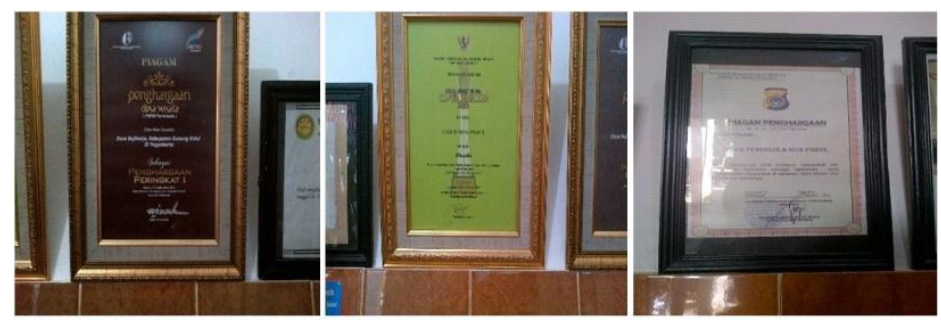

Figure 1. Certificates for Pokdarwis Dewa Bejo

According to the Head of Pokdarwis Dewa Bejo, Subagyo, the locals have certain agreement to share profit. $50 \%$ of the profitisgivento84touristguides, $25 \%$ of the profit is given to Pokdarwis Dewa Bejo committees and the remaining 25\% is considered as safe. Based on the agreement, the tour guides received 200,000/day or between 1.5 million and 3 million rupiahs/month depending upon number of visitors. Recently, thereareatleast800individualsincludingotherPokdarwis-

Pokdarwis who rely on Gua Pindul. Gua Pindul has become the magnet for both the locals and visitors. Gua Pindul has created significant amount of job vacancy and solved poverty. Young locals are no longer interested in finding job in other areas because they can get sufficient income while developing their own village.

Besides the ones responsible for tourist management in Gua Pindul, the society and the local government are taking advantage of Gua Pindul. The local society is taking turn to provide some food for the tourists. The local government gets their share from Gua Pindul for 75 years (starting from 2013) and is given authority to manage stores around Gua Pindul. The locals are also responsible for parking fee and are allowed to rent their houses as homestay for visitors.

It is clear that Gua Pindul has helped the locals becoming financially independent. The locals do not have to travel to other areas to find job. Bejiharjo has transformed into tourist village that provides for the locals. 
Vol. 1 No.1

March2018

122

Gua Pindul has also created multiplier effect. As tourist attraction, Gua Pindul has positive contribution to those responsible for its management, as well as those providing related facilities for visitors coming to Gua Pindul, for example homestay owners, food stall owners, and small clothing shop owners. Gua Pindul has become the source of income for these types of people.
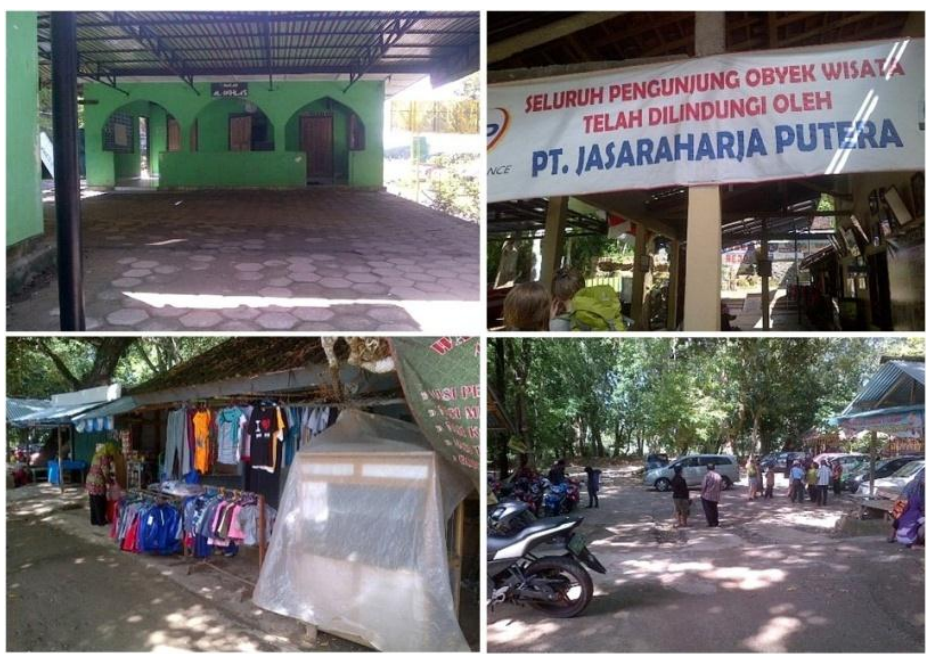

Figure 2. Infrastructure and Facilities in Gua Pindul

Increasing number of visitors has motivated the management to become more professional and improve some facilities such as providing cave tubing gears (safety jackets, tube, helmet, and shoes), mosque, toilet and changing room, as well as storage for visitor's belonging. Foreign language training such as English, Japanese, Korean and Spain is conducted for the tourist guides so that they can interact with foreign visitors. Besides foreign language training, the tour guides also attend safety training facilitated by Basarnas and other trainings of which topics are to develop tourism sector facilitated by the regional government. The management has also designed other tourist packages that allow visitors to enjoy both the nature and cultural heritage in Bejiharjo village. At last, the management 
worked together with PT. Jasa Raharja Putera, a leading insurance company to provide insurance for the visitors.

In conclusion, the article describes an example of community-based local economic development in which tourism becomes the main subject. Munir mentioned that Local Economic Development (LED) refers to process in which actors in a city or district (government, civilian and entrepreneur) work collectively to trigger growth of economics, create job vacancy, and help local government to serve their community well (Munir and Fitanto 2005). LED, as a model, emphasizes on formulating indigenous development policies using as many local aspects in development which involves human resource, natural resource, man-made resource and institution. Indicators frequently used are increase or creation of job vacancy and use of local commodity. The objective of LED is to increase number and type of job vacancy for the locals (Leigh and Blakely 2016). Maliza and Feser describe that several steps in administration of LED are(a) organizing the effort a step in which stakeholders establish vision, commitment and agreement for developing local economics,(b)local economy assessment, identification or effort to understand characteristics of local economics to help stakeholders develop strategies in the future and design program alternatives,(c)strategy making, providing ideal and unique illustration on program or activity to develop,(d)strategy implementation, strategy running based on plan designed previously and also related to implementation of LED strategy (who is doing what role),(e)strategy review, review about accessible resource in an effort to achieve strategy (Malizia and Feser 1999).

\section{Conclusion: Indigenizes as capital to compete with Globalization}

A successful tourism development is the development of tourism can provide advantages in economy, social and culture to local people. This proves that the development of Caves 
tourism Pindul has managed to improve the well-being and quality of life of the local community. Community empowerment which is bottom up has been able to revamp the villagers Bejiharjo the poor and backward into a developed society and being able to full fill the needs of life. Pindul cave has become a source of life for local people who now dont have to wander into town in favor of job search. This means that the development of community-based tourism has managed to become an industry capable of creating economic growth thus created the welfare of local communities.

Community-based Tourism Development that was capable of creating local economies through the empowerment way turns out to be a reference or an example of the management of tourism in the world including in ASEAN countries. This confirms that by empowering community featuring local wisdom thus became an option in an effort to manage the tourism sector, while simultaneously demonstrating that indigenizes the culture, customs, and habits habits that do local communities have been able to compete with the tourism sector which offers the concept of modernity. Thus, many travelers seek tourism objects that offer tradisionalitas as well as local wisdom in keeping their environment.

The development of community-based tourism aims to: 1) empowering communities through the development of tourism; 2) improving the role and participation of the community in the development of tourism in order to gain economic,socialandculturaldevelopmentoftourism;3)gives a balanced opportunity to all members of society both men and women (gender based and equity) (Demartoto 2009). This approach also encourages the community to feel to have (sense of belonging) against the wealth of good nature and culture tourism development as an asset. So, the community will continue to maintain and preserve what they are holding with the local wisdom that kept guarded. 
To manage and develop community-based tourism is the other thing to note is to maintain unique values such as customs, traditional care monies, beliefs, traditional performances, and art the art of craft owned by the local community. With the development of community-based tourism which offer cultural indigenizes local community thus becomes a magnet for tourists to visit and enjoy everything it has to offer in the area. So,with raised indigenizes (local) or local wisdom as a tour package which is packaged in such away, wearable to compete with modern International tourism and thus become the main direction in the management of tourism empowering local communities while creating.

\section{REFERENCES}

Babbie, E. R. (2015). The practice of social research, Nelson Education.

Demartoto, A. (2009). Pembangunan pariwisata berbasis masyarakat, Sebelas Maret University Press.

Denzin, N. K. and Y. S. Lincoln (1994). Handbook of qualitative research, Sage publications, inc.

Esterberg, K. G. (2002). "Qualitative methods in social research."

Gelgel, I. P. (2006). Industri pariwisata Indonesia dalam globalisasi perdagangan jasa (GATS-WTO): implikasi hukum dan antisipasinva, Refika Aditama.

L BERG, B. (2001). "Qualitative research methods for the social sciences."

Leigh, N. G. and E. J. Blakely (2016). Planning local economic development: Theory and practice, SAGE publications.

Malizia, E. E. and E. J. Feser (1999). Understanding local economic development, Routledge.

Moleong, L. J. (2008). "Methodology of Qualitative Research." Revision edition. Bandung: Remaja Rosdakarya.

Munir, R. and B. Fitanto (2005). Pengembangan ekonomi lokal partisipatif: masalah, kebijakan, dan panduan pelaksanaan kegiatan, Local Governance Support Program.

Oka, A. "Yoeti. 1982." Pengantar Ilmu Pariwisata.

Othman, P. and M. M. Rosli (2011). "The impact of tourism on small business performance: Empirical evidence from Malaysian islands." International Journal of Business and Social Science 2(1). 
Pitana, I. (2009). "dan Diarta. 2009 " Pengantar Ilmu

Satria, A. (2005). "Sawen: institution, local knowledge and myth in fisheries management in North Lombok, Indonesia." Fishers' Knowledge in Fisheries Science and Management.

Setyawan, A. (2008). Analisis Permintaan Listrik Rumah Tangga (R1-900 Va) di Kabupaten Sukoharjo Tahun 1981-2005, Universitas Muhammadiyah Suirakarta.

Suasapha, A. H. (2016). "Implementasi Konsep Pariwisata Berbasis Masyarakat Dalam Pengelolaan Pantai Kedonganan." Jurnal Master Pariwisata (Jumpa).

Sugiantoro, R. (2000). "Pariwisata Antara Obsesi dan Realita." Yogyakarta. Adicita Karya Nusa.

Widowati, S. (2012). "Kajian Potensi dan Evaluasi Penerapan Prinsip-prinsip dan Kriteria Ekowisata di Kawasan Taman Wisata Alam Kawah Ijen, Desa Taman Sari, Kabupaten Banyuwangi." Denpasar: Universitas Udayana.

Yin, R. K. (2009). "Case study research: Design and methods (applied social research methods)." London and Singapore: Sage. 